\title{
PENGARUH PERSEPSI EXPRESSIVENESS, MANFAAT, KEMUDAHAN PENGGUNAAN, NORMA SOSIAL DAN PERSEPSI KUALITAS SISTEM TERHADAP NIAT NASABAH MENGGUNAKAN SMS BANKING DENGAN GENDER SEBAGAI VARIABEL MODERASI PADA BANK BRI DI SURABAYA
}

\author{
Rahayu \\ Universitas Islam Majapahit (UNIM) Mojokerto \\ Email : rahayubasudewa@yahoo.com
}

\begin{abstract}
The combination of cellular telephone technology with internet technology lately is increasingly rife discussed. The analysis in this study was criticized that the population was customers who had savings in BRI Surabaya and had not used BRI SMS banking services, with a sample requirement of 100 respondents. The results of the study indicate that the perceived benefits affect the intention to use SMS banking more strongly in men than women. Then the hypothesis is accepted, because it can be seen from the value of the beta coefficient in men the value of the beta coefficient (0.432) is greater than women whose beta coefficient value (0.225). Perceived ease of use affects the intention to use SMS banking more strongly in women than men. Then the hypothesis is accepted, with a beta coefficient value (-0.188) smaller than women whose beta coefficient value (0.286). Social norms affect the intention to use SMS banking more strongly in women than men. Then the hypothesis is rejected, because it can be seen from the value of the beta coefficient, where in men the value of the beta coefficient (0.314) is greater than women whose beta coefficient value (0.191). The perceived quality of the system influences the intention to use SMS banking more strongly in men than in women. Then the hypothesis is rejected, because it can be seen from the value of the beta coefficient, where in men the value of the beta coefficient (0.398) is smaller than women whose beta coefficient value (0.429). This is due to the fact that women in Surabaya are considered more to consider risk, safety and quality Keyward: customer intentions, gender, sms banking
\end{abstract}

\begin{abstract}
ABSTRAK
Perpaduan antara teknologi telepon seluler dengan teknologi internet belakangan ini semakin marak dibahas. Analisa dalam penelitian ini dikriteriakan bahwa populasinya yaitu nasabah yang memiliki tabungan di BRI Surabaya dan belum menggunakan layanan SMS banking BRI, dengan ketentuan sampel sejumlah 100 responden. Adapun hasil penelitian menunjukkan bahwa persepsi manfaat mempengaruhi niat untuk menggunakan SMS banking lebih kuat pada laki-laki dibandingkan perempuan. Maka hipotesis diterima, karena dapat dilihat dari nilai koefisien beta pada laki-laki nilai koefisien beta $(0,432)$ lebih besar dari perempuan yang nilai koefisien beta $(0,225)$. Persepsi kemudahan penggunaan mempengaruhi niat untuk menggunakan SMS banking lebih kuat pada perempuan dibandingkan laki-laki. Maka hipotesisi diterima, dengan nilai koefisien beta $(-0,188)$ lebih kecil dari perempuan yang nilai koefisien beta $(0,286)$. Norma sosial mempengaruhi niat untuk menggunakan SMS banking lebih kuat pada perempuan dibandingkan laki-laki. Maka hipotesis ditolak, karena dapat dilihat dari nilai koefisien beta, dimana pada laki-laki nilai koefisien beta $(0,314)$ lebih besar dari perempuan yang nilai koefisien beta $(0,191)$. Persepsi kualitas sistem mempengaruhi niat untuk menggunakan SMS banking lebih kuat pada laki-laki dibandingkan perempuan. Maka hipotesis ditolak, karena dapat dilihat dari nilai koefisien beta, dimana pada laki-laki nilai koefisien beta $(0,398)$ lebih kecil dari perempuan yang nilai koefisien beta $(0,429)$. Hal ini disebabkan bahwa perempuan di Surabaya dianggap lebih mempertimbangkan resiko, keamanan dan kualitas
\end{abstract}

Keyward : niat nasabah, gender, sms banking

J-MACC : Journal of Management and Accounting 


\section{PENDAHULUAN}

Era perdagangan bebas saat ini, dituntut berbagai kemudahan dalam melakukan transaksi perdagangan maupun aktifitas lainnya, teknologi berperan penting sebagai upaya untuk mendukung berbagai aktifitas khususnya bidang ekonomi. Ketatnya persaingan dalam dunia usaha maka peran perbankan menjadi tolok ukur dalam kemuudahan melakukan transaksi terutama transaksi bersifat digitalisasi. Dimana fungsi perbankan sebagai lembaga intermediasi sangat berperan dalam percepatan pertumbuhan ekonomi dari keputusan bisnis yang merupakan kebutuhan dari masyarakat untuk melakukan suatu aktivitas perekonomian.

Kotler dan Keller (2006:31) mengungkapkan bahwa dewasa ini dunia bisnis menghadapi tiga tantangan dan peluang utama yaitu globalisasi, kemajuan teknologi, dan deregulasi. Hal ini berarti tantangan yang ada menjadi peluang yang dapat dimanfaatkan perusahaan untuk bertahan dan memiliki performa yang lebih baik dari sebelumnya. Tidak dapat dipungkiri bahwa globalisasi dan deregulasi telah meningkatkan persaingan pasar. Seperti saat ini perusahaanperusahaan menjadi lebih mudah melewati batas dan bersaing secara internasional. Persaingan tinggi membuat organisasi-organisasi menaikkan tingkat produktivitas dan mengurangi biaya.

Teknologi informasi yang canggih dan handal menjadi parameter kemapanan sebuah bank. Bank berlomba-lomba memantapkan infrastruktur teknologi informasinya. Dengan sistem informasi teknologi yang memadai, bank mampu bertahan dan berkembang di tengah persaingan yang kian sengit dan mengglobal. Akibat perubahan teknologi yang begitu cepat, berimbas juga kepada perubahan perilaku masyarakat. Informasi dengan mudah diperoleh dan diserap oleh masyarakat sekalipun di pelosok pedesaan yang terpencil. Imbas yang paling nyata adalah masyarakat pandai dalam memilih produk yang sejenis, tentu saja dalam arti yang sesuai dengan keinginan dan kebutuhan mereka.

Bank sebagai lembaga keuangan yang menghasilkan jasa keuangan juga membutuhkan strategi pemasaran untuk memasarkan produk. Dampak dari perubahan teknologi juga berdampak positif terhadap perkembangan dunia perbankan. Dampak negatif bagi bank adalah tingginya biaya untuk membeli teknologi tersebut. Belum lagi masalah keamanan menjadi prioritas utama. Oleh karena itu, dalam era teknologi yang berkembang demikian cepat ini saatnya bank menjemput bola dan mengejar nasabah bukan menunggu nasabah, karena dalam kondisi ini nasabah bukan lagi sebagai pelengkap usaha tetapi sebagai partner usaha bagi bank.

Bank harus pandai membaca keinginan dan kebutuhan nasabahnya dengan memberikan persepsi yang positif kepada nasabahnya akan manfaat dan kemudahan penggunaan dalam 
bertransaksi seperti e-banking yang terdiri dari internet banking, mobile banking, phone banking dan SMS banking (www.bi.go.id), agar nasabah dapat melakukan transaksi perbankan dimana saja dan kapan saja dua puluh empat jam sehari, tujuh hari dalam seminggu dengan mudah dan praktis.

Perpaduan antara teknologi telepon seluler dengan teknologi internet belakangan ini semakin marak dibahas. Telepon seluler, saat ini banyak digunakan untuk mendapatkan informasi serta berbagai layanan yang dibutuhkan konsumen. Maraknya pengguna teknologi canggih di sektor perbankan dipastikan akan mengubah pola transaksi. Bank yang tadinya lebih banyak disibukkan dengan transaksi yang berkaitan dengan uang tunai, penarikan dan penyetoran uang, menjadi lebih praktis dan cepat tanpa antri. Produk yang mengimplementasikan perbankan dengan teknologi informasi atau yang biasa disebut mobile banking, terus berkembang sering dengan menjamurnya pengguna handphone.

Technology Acceptance Model (TAM) merupakan model yang populer dan banyak digunakan dalam berbagai penelitian mengenai proses adopsi teknologi informasi. TAM diperkenalkan pertama kali oleh Fred Davis dalam penelitiannya di tahun 1986, secara garis besar menjelaskan tentang bagaimana perilaku pengguna dalam menerima dan menggunakan teknologi baru. Tujuan dari Technology Acceptance Model (TAM) atau model penerimaan teknologi ini untuk memberikan penjelasan tentang faktor yang menentukan penerimaan komputer secara umum, mampu menjelaskan perilaku pengguna. Technology Acceptance Model (TAM) dipengaruhi oleh beberapa variabel yaitu variabel perceived usefulness dan variabel perceived easy of use, dimana kedua variabel tersebut berpengaruh terhadap attitude toward using technology. Attitude toward using technology berpengaruh terhadap intention to use, kemudian intention to use berpengaruh terhadap actual use of technology.

Tujuan utama TAM adalah untuk memberikan dasar penelusuran tentang faktor-faktor utama dari perilaku pengguna dengan dimensi-dimensi tertentu yang dapat mempengaruhi diterimanya teknologi informasi oleh pengguna. TAM menjelaskan ada dua faktor yang secara domman mempengaruhi integrasi teknologi. Faktor pertama adalah persepsi pengguna terhadap manfaat teknologi (perceived usefulness) dan faktor kedua adalah persepsi pengguna terhadap kemudahan penggunaan teknologi (perceived easy of use), dimana kedua faktor tersebut mempengaruhi sikap pengguna (attitude toward using) dalam penerimaan teknologi tersebut dan juga berpengaruh terhadap niat. Selanjutnya niat untuk memanfaatkan teknologi (intention to use) mempengaruhi penggunaan yang sesungguhnya (actual usage). Dengan pertimbangan uraian di atas maka penelitian ini penting untuk dilakukan. 


\section{Rumusan Masalah}

Berdasarkan latar belakang yang telah diuraikan diatas, maka permasalahan penelitian dapat dirumuskan sebagai berikut :

1. Apakah persepsi expressiveness berpengaruh terhadap niat nasabah untuk menggunakan SMS banking lebih kuat pada perempuan dibandingkan laki-laki.

2. Apakah persepsi manfaat berpengaruh terhadap niat nasabah untuk menggunakan SMS banking lebih kuat pada laki-laki dibandingkan perempuan.

3. Apakah persepsi kemudahan penggunaan berpengaruh terhadap niat nasabah untuk menggunakan SMS banking lebih kuat pada perempuan dibandingkan laki-laki.

4. Apakah norma sosial berpengaruh terhadap mat nasabah untuk menggunakan SMS banking lebih kuat pada perempuan dibandingkan lakilaki.

5. Apakah persepsi kualitas sistem berpengaruh terhadap niat nasabah untuk menggunakan SMS banking lebih kuat pada laki-laki dibandingkan perempuan.

\section{Tujuan Penelitian}

Adapun tujuan penelitian ini adalah:

1. Untuk mengetahui pengaruh persepsi expressiveness terhadap niat nasabah untuk menggunakan SMS banking pada perempuan dibandingkan laki-laki.

2. Untuk mengetahui pengaruh persepsi manfaat terhadap niat nasabah untuk menggunakan SMS banking pada laki-laki dibandingkan perempuan.

3. Untuk mengetahui pengaruh persepsi kemudahan penggunaan terhadap niat nasabah untuk menggunakan SMS banking pada perempuan dibandingkan laki-laki.

4. Untuk mengetahui pengaruh norma sosial terhadap niat nasabah untuk menggunakan SMS banking pada perempuan dibandingkan laki-laki.

5. Untuk mengetahui pengaruh persepsi kualitas sistem terhadap niat nasabah untuk menggunakan SMS banking pada laki-laki dibandingkan perempuan.

\section{LANDASAN TEORI}

\section{Karakteristik Jasa Bank}

Sebagaimana produk, jasa juga memiliki karakteristik-karakteristik tertentu yang membedakannya dari produk. Karakteristik ini melekat pada jasa dan membuat jasa menjadi output yang unik. Jasa memiliki empat karakteristik yang sangat mempengaruhi rancangan program pemasaran. Karakteristik jasa dengan bank sebagai salah satu penyedia jasa menurut Sumarni (2002 : 258) adalah :

1. Tidak berwujud 
Pihak pembeli harus percaya kepada si penjual jasa. Sebaliknya penjualan jasa harus mengupayakan untuk meningkatkan kepercayaan pembeli misalnya, dengan cara lebih meningkatkan wujud jasa secara konkrit. Pemasar bank harus menekankan manfaat jasa bank kepada nasabah dan bukan sekedar ciri-ciri jasa bank tersebut. Seorang nasabah seharusnya merasa puas sekeluarnya dari bank, setelah menerima penjelasan dari petugas bank mengenai manfaat dan kemudahan atau fasilitas tambahan yang disediakan bagi penabung di bank tersebut.

\section{Tidak terpisahkan}

Jasa bank dan petugas bank tidak dapat dipisahkan sekalipun petugas tersebut digantikan oleh mesin. Untuk mempercepat layanan petugas bank dapat dibantu dengan peralatan elektronik yang diperlukan sehingga akan dapat melayani lebih banyak nasabah.

3. Keanekaragaman

Ternyata jasa bank cukup beragam. Nasabah seringkali membicarakan atau berkonsultasi dengan pemasar jasa bank sebelum memutuskan pilihannya. Disini manajemen bank harus tanggap yaitu menyediakan tenaga penjual yang sudah terlatih secara profesional dan kemudian setelah itu memantau kepuasan nasabah melalui sistem kontak untuk menyampaikan keluhan.

4. Tidak tahan lama

Jasa bank tidak dapat disimpan atau dibeli dulu untuk persediaan. Keinginan nasabah untuk dilayani 24 jam dapat disediakan bank melalui Authomatic Teller Machine (ATM) atau electronic banking.

\section{Niat Beli (Purchase Intention)}

Niat pembelian merupakan salah satu tahapan dari tanggapan konsumen dalam memutuskan, menjaga, atau bahkan membuang produk tertentu. Niat beli (purchase intention), merupakan pemikiran konsumen tentang apa yang akan mereka bell (Engel et al., 1995).

Seth et al (1999) mengatakan bahwa niat yang dimiliki seseorang menunjukkan seberapa besar kemungkinan dituiukannya perilaku tertentu oleh orang tersebut. Apabila niat yang dimiliki oleh konsumen tersebut kuat, maka dia akan berupaya untuk menempuh berbagai cara untuk menunjukkan perilakunya demi mencapai tujuan dalam memenuhi niatnya, dan sebaliknya apabila niat yang dimiliki konsumen itu lemah, maka dia akan membatalkan dan menggagalkan usahanya sebagai bentuk perilaku. Niat pada diri konsumen akan mendorongnya untuk melakukan perilaku yang diinginkan, sehingga dapat mencerminkan seberapa jauh 
konsumen akan melakukan perilaku tersebut. Olson et al (2001) mengatakan bahwa niat beli konsumen dapat diartikan sebagai perintah dalam diri konsumen untuk membeli merek atau produk yang sedang diinformasikan, atau kemungkinan melakukan tindakan yang berhubungan dengan pembelian.

\section{Technology Acceptance Model (TAM)}

Technology Acceptance Model (TAM) adalah model yang disusun oleh Davis (1986) untuk menjelaskan penerimaan teknologi yang akan digunakan oleh pengguna teknologi. Dalam memformulasikan TAM, Davis menggunakan TRA sebagai grand theorynya namun tidak mengakomodasi semua komponen teori TRA. Davis hanya memanfaatkan komponen Belief dan Attitude raja, sedangkan Normative Belief dan Subjective Norms tidak digunakannya. Secara skematis teori TAM yang dikutip oleh Ramdhani (2007) digambarkan sebagai berikut:

Gambar 1 Technology Acceptance Model 1

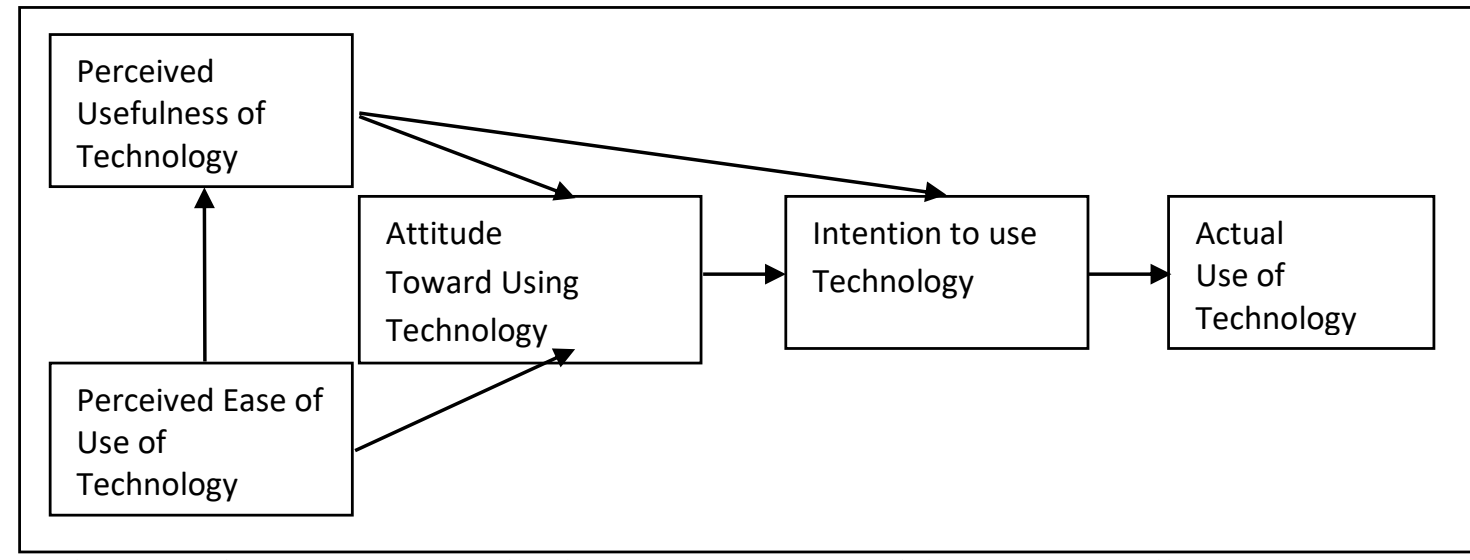

Sumber: Davis,F.D. 1986. Technology Acceptance Model for Empirically Testing New End User Information Systems Theory and Result. Unpublished Doctoral Disertation MIT, dalam Ramdhani, Neila. 2007. Model Perilaku Penggunaan IT : Pengembangan Dari Technology Acceptance Model.

Menurut Davis (1986) perilaku menggunakan informasi teknologi diawali oleh adanya persepsi mengenai manfaat (perceived usefulness) dan persepsi mengenai kemudahan menggunakan teknologi informasi (perceived ease of use). Kedua komponen ini bila dikaitkan dengan TRA adalah bagian dari belief. Agak berbeda dengan persepsi individu terhadap kegunaan teknologi informasi ini, variabel lain yang dikemukakan Davis mempengaruhi kecenderungan individu menggunakan teknologi informasi adalah persepsi terhadap kemudahan dalam menggunakan teknologi informasi. Faktor persepsi terhadap manfaat teknologi informasi (perceived usefulness) dan faktor persepsi terhadap kemudahan penggunaan teknologi informasi (perceived ease of use), mempengaruhi sikap (attitude) individu terhadap penggunaan teknologi informasi, yang selanjutnya akan menentukan apakah orang berniat untuk menggunakan 
informasi teknologi (intention). Niat untuk menggunakan teknologi informasi akan menentukan apakah orang akan menggunakan informasi teknologi (behavior).

Gambar 2 Technology Acceptance Model 2

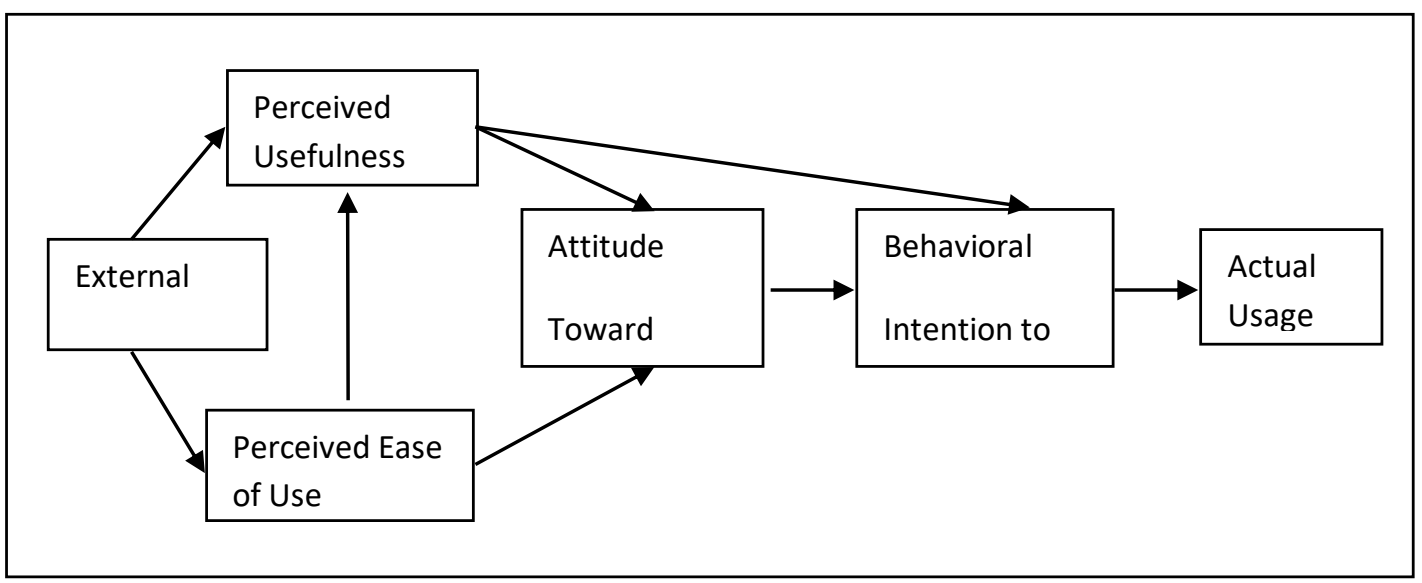

Sumber: Davis, F. D. 1989. Perceived Usefulness, Perceived Ease of Use, and User Acceptance of Information Technology. MIS Quarterly, Vol. 13, No. 3, pp. 319-340.

Menurut Davis (1989), bahwa persepsi terhadap manfaat teknologi informasi juga mempengaruhi persepsi kemudahan penggunaan teknologi informasi tetapi tidak berlaku sebaliknya. Dengan demikian, selama individu merasa bahwa teknologi informasi bermanfaat dalam tugas-tugasnya, ia akan berniat untuk menggunakannya terlepas apakah teknologi informasi itu mudah atau tidak mudah digunakan. Hal ini menunjukkan bahwa persepsi individu terhadap kemudahan dalam menggunakan teknologi informasi berkorelasi dengan penggunaan teknologi informasi saat ini dan keinginan untuk menggunakannya di masa yang akan datang.

Dan kemudian TAM direvisi oleh Davis et al. (1989) dengan menghilangkan variabel sikap dar model awal yang telah diciptakan. Penyebabnya adalah variabel sikap tidak secara penuh menjadi mediating variable dalam hubungan antara perceived usefulness dan perceived ease of use dengan behavioral intention. Revisi model TAM yang tidak melibatkan variabel sikap berhasil diteliti oleh Venkatesh dan Davis (1996), selain itu disusul penelitian selanjutnya oleh Venkatesh (1999), Venkatesh dan Davis (2000), Venkatesh dan Moris (2000), Gefen, et al. (2003).

\section{Persepsi Expressiveness}

Banyak cara untuk mengekspresikan emosi/ identitas seseorang, misalnya dengan mengirim/ menerima SMS dan email, yang merupakan aktivitas berkomunikasi untuk menunjukkan style dan kehidupan bermasyarakat (Nysveen, 2005). Menurut Nysveen, et al. (2005) expressiveness sama halnya dengan motivasi untuk menggunakan dan atau menyatakan 
sesuatu.

\section{Persepsi Manfaat}

Davis (1989) mendefinisikan persepsi manfaat adalah keyakinan seseorang bahwa dengan menggunakan teknologi informasi atau inovasi yang baru maka akan dapat meningkatkan kinerja dari perilakunya. Yang berdasarkan dari definisi kata useful yaitu capable of being used advantageously atau dapat digunakan untuk tujuan yang menguntungkan. Persepsi manfaat sebagai keyakinan seseorang bahwa teknologi berguna dalam melakukan transaksi perbankan (Wang, et al., 2003).

Dari definisi tersebut di atas, dapat diartikan bahwa kemanfaatan dari penggunaan teknologi dapat meningkatkan kinerja. Individu akan mengumpulkan banyak informasi mengenai manfaat yang didapat dalam teknologi tersebut sebelum memutuskan akan menggunakan atau tidak.

\section{Persepsi Kemudahan Penggunaan}

Menurut Davis (1989) kemudahan (ease) bermakna tanpa kesulitan/ terbebaskan dari kesulitan / tidak perlu berusaha keras. Persepsi kemudahan penggunaan berarti keyakinan seseorang bahwa sistem teknologi informasi yang digunakan tidak merepotkan atau tidak membutuhkan usaha yang besar. Kemudahan dalam penggunaan suatu teknologi informasi ini mampu memberikan indikasi bahwa bekerja dengan teknologi akan menjadi lebih mudah bila dibandingkan dengan orang yang bekerja secara manual tanpa menggunakan teknologi informasi. Menurut Zeithaml, et al (2002) dalam Jahangir dan Begum (2008) persepsi kemudahan penggunaan adalah tingkat dimana inovasi/ teknologi dirasakan mudah untuk dimengerti atau digunakan. Menurut Shen dan Eder (2009) menguji latar belakang dari persepsi kemudahan penggunaan adalah penting bukan hanya dikarenakan mampu berpengaruh secara langsung dan tidak langsung pada niat perilaku penggunaan tetapi lebih dikarenakan persepsi tersebut merupakan persepsi yang paling mendasar yang ada dalam diri pengguna selama tahap awal menggunakna teknologi baru.

\section{Norma Sosial}

Social norm atau subjective norm atau seringkali disebut sebagai social pressure merupakan suatu pengaruh atas referensi orang lain, yaitu keyakinan individu tentang setuju atau tidaknya seseorang atau suatu kelompok terhadap individu tersebut untuk melakukan atau tidak melakukan suatu perilaku tertentu dan sejauh mana individu tersebut termotivasi untuk mengikuti atau tidak mengikuti apa yang diharapkan oleh orang lain atau kelompok lain terhadapnya (Ajzen, 1991 dikutip oleh Bobeck dan Hatfield, 2003). Menurut Ancok (1995: 5) 
bahwa subjective norm merupakan komponen yang berisikan keputusan yang dibuat oleh individu setelah mempertimbangkan pandangan orang-orang yang mempengaruhi norma-norma subjektif tentang perilaku tertentu. Norma subjektif seseorang merupakan produk dari keyakinan bahwa orang lain berpendapat sebaiknya konsumen melakukan atau tidak melakukan perilaku tertentu dan motivasi seseorang untuk menuruti pendapat tersebut.

\section{Persepsi Kualitas Sistem}

Persepsi kualitas sistem diartikan tingkat keyakinan seseorang dimana jasa atau produk tersebut memberikan persepsi kualitas yang lebih baik, terhindar dari kerusakan, terhindar dari penundaan dan waktu responnya baik (Amin, 2007). Amin (2007) kualitas sistem meliputi keamanan, sistem mudah untuk digunakan, waktu respon dan kualitas informasi yang diterima dalam menggunakan teknologi informasi. Menurut Amin (2007), kualitas sistem sangat penting pada layanan SMS banking, karena nasabah akan enggan untuk menggunakan sistem SMS banking ketika layanan tersebut sering tertunda responnya, koneksinya sering terputus dan kurang aman.

\section{Pengertian SMS BANKING}

SMS banking adalah layanan teknologi dari bank kepada nasabah, yang memungkinkan mereka untuk mengoperasikan layanan perbankan melalui partisi telepon seluler menggunakan pesan SMS (http://en.wikipedia.org/wiki/SMS banking). SMS banking adalah layanan informasi perbankan yang dapat diakses langsung melalui telepon seluler/ handphone dengan menggunakan media SMS (Short Message Service) (www.bi.go.id).

Menurut Amin (2007) SMS banking adalah transaksi perbankan dalam bentuk Short Message Service (SMS) dengan menggunakan mobile banking. Dulunya, SMS merupakan sarana komunikasi dengan keluarga, teman maupun guru. Tetapi, sekarang SMS berkembang penggunaannya sebagai informasi perbankan untuk membuat nasabah dan bank lebih baik. SMS banking adalah transaksi perbankan menggunakan handphone via aplikasi SMS (Amin, et al 2006:22)

\section{Gender dan Niat Menggunakan SMS Banking}

Handayani dan Sugiarto (2001: 4) berpendapat bahwa gender adalah sifat yang melekat pada laki-laki dan perempuan yang dibentuk oleh faktor-faktor sosial maupun budaya, sehingga lahir beberapa anggapan tentang peran sosial budaya laki-laki dan perempuan, misalnya lakilaki digambarkan memiliki sifat maskulin seperti keras, kuat, rasional dan jantan dan perkasa. Sementara perempuan digambarkan memiliki sifat feminin sepert lemah lembut, cantik, emosional/keibuan. Relatif berubah mengikuti nilai-nilai dari budaya atau masyarakat setempat. 
Oleh karena itu, sifat-sifat tersebut dapat dipertukarkan/ berubah dari waktu ke waktu dari tempat ke tempat lain, perubahan ini tidak hanya tedadi dalam lingkup privat seperti rumah tangga tapi juga tempat kerja dan masyarakat. Sedangkan menurut Fakih dalam Kuntari (2001) gender adalah penggolongan gramatikal terhadap kata-kata benda dan kata-kata lainnya yang berhubungan dengannya, yang secara garis besar berhubungan dengan dua jenis kelamin.

Darley dan Smith (1995) berpendapat bahwa alasan kenapa gender lebih sering digunakan sebagai segmentation strategy terdiri dari tiga hal. Pertama, informasi gender lebih mudah untuk dikenali dan diperoleh. Kedua, gender dapat diukur dan responsive pada unsur-unsur marketing mix. Ketiga, jumlah gender cukup besar dan menguntungkan. Amin (2007) menganggap bahwa dengan mengidentifikasi gender lebih menguntungkan karena adanya implikasi pemasaran dan dapat memberikan masukan kepada bank, sehingga bank dapat secara efektif melakukan promosi tentang SMS banking. Dalam hal ini, pihak bank tidak hanya bertujuan meminimalisir biaya promosi saja tapi juga agar nasabah berniat dan mau menggunakan sistem teknologi SMS banking.

\section{Penelitian Sebelumnya}

Penelitian sebelumnya dilakukan oleh Hanudin Amin berjudul Extending The Technology Acceptance Model for SMS Banking : Analyzing The Gender Gap Among Students, merupakan perluasan dari variabel Technology Acceptance Model (TAM) yang diteliti oleh Fred Davis (1986). Dimana variabel Technology Acceptance Model TAM, yaitu persepsi manfaat (perceived usefulness) dan persepsi kemudahan penggunaan (perceived ease of use) ditambahkan lagi variabelnya, yaitu persepsi expressiveness (perceived expressiveness), norma sosial (social norm), persepsi kualitas sistem (perceived system quality) berpengaruh terhadap niat untuk menggunakan (intention to use) dengan gender sebagai variabel moderasi pada penggunaan SMS banking. Persepsi expressiveness, persepsi manfaat, persepsi kemudahan penggunaan, norma sosial dan persepsi kualitas sistem berpengaruh juga terhadap sikap (attitude towards use). Yang kemudian sikap berpengaruh terhadap niat untuk menggunakan.

Amin (2007) menemukan bahwa variabel penting yang menentukan mat nasabah untuk menggunakan SMS banking pada perempuan adalah variabel persepsi expressiveness, persepsi kemudahan penggunaan, norma sosial, sedangkan pada laki-laki adalah variabel persepsi manfaat dan persepsi kualitas sistem. Secara empiris, sikap untuk menggunakan SMS banking mempunyai pengaruh yang signifikan untuk laki-laki dan perempuan, dimana laki-laki lebih kuat dibanding perempuan.

Persamaannya dengan penelitian ini, variabel yang diteliti adalah persepsi expressiveness, persepsi manfaat, persepsi kemudahan penggunaan, norma sosial dan persepsi kualitas sistem 
berpengaruh terhadap niat untuk menggunakan SMS banking dengan gender sebagai variabel moderasi. Perbedaannya, pada penelitian ini menggunakan populasi satu bank saja, sedangkan pada panelitian Amin (2007) menggunakan beberapa bank di Malaysia dan sampel penelitiannya adalah mahasiswa. Dalam penelitian ini variabel sikap (attitude) dihilangkan karena tidak secara penuh menjadi mediating variable dalam hubungan antara perceived usefulness dan perceived easy of use dengan intention to use (Davis, et al., 1989)

\section{Model Analisis}

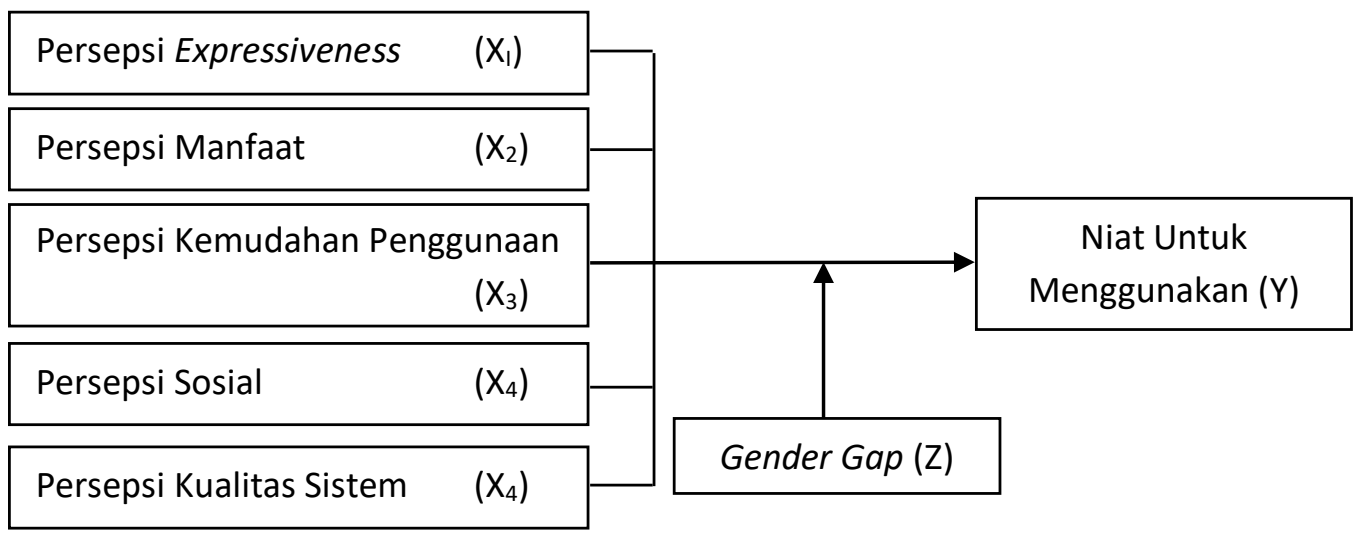

Sumber: Amin, Hanudin. 2007 Extending The Technology Acceptance Model For SMS Banking: Analyzing The Gender Gap Among Students. International Journal of Business and Society, Vol. 8, No. 1, pp 15-27.

\section{Hipotesis}

$\mathrm{H}_{1}$ : Persepsi expressiveness berpengaruh terhadap niat untuk menggunakan SMS banking lebih kuat pada perempuan dibandingkan laki-laki.

$\mathrm{H}_{2}$ : Persepsi manfaat berpengaruh terhadap niat untuk menggunakan SMS banking lebih kuat pada laki-laki dibandingkan perempuan.

$\mathrm{H}_{3}$ : Persepsi kemudahan penggunaan berpengaruh terhadap niat untuk menggunakan SMS banking lebih kuat pada perempuan dibandingkan laki-laki.

$\mathrm{H}_{4}$ : Norma sosial berpengaruh terhadap niat untuk menggunakan SMS banking lebih kuat pada perempuan dibandingkan laki-laki.

$\mathrm{H}_{5}$ : Persepsi kualitas sistem berpengaruh terhadap niat untuk menggunakan SMS banking lebih kuat pada laki-laki dibandingkan perempuan.

\section{METODE PENELITIAN}

\section{Identifikasi Variabel}

Variabel bebas dalam penelitian ini adalah persepsi expressiveness $\left(\mathrm{X}_{1}\right)$, persepsi manfaat $\left(\mathrm{X}_{2}\right)$, persepsi kemudahan penggunaan $\left(\mathrm{X}_{3}\right)$, norma social $\left(\mathrm{X}_{4}\right)$ dan persepsi kualitas sistem $(\mathrm{X} 5$ 
). Variabel tergantung dalam penelitian ini adalah niat untuk menggunakan. Variabel Moderating (Z) gender.

\section{Populasi dan Sampel Penelitian}

Populasi penelitian ini adalah nasabah yang memiliki tabungan di BRI Surabaya dan belum menggunakan layanan SMS banking BRI, tapi sudah mengetahui tentang layanan SMS banking BRI. Penentuan sampel penelitian dilaksanakan dengan menggunakan metode non probability sampling, yaitu pengambilan sampel didasarkan pada pertimbangan (judgement) peneliti, bukan peluang unit sampel untuk terpilih (Simamora , 2004: 197).

Teknik sampling dilakukan dengan teknik purposive sampling dan accidental sampling. Menurut Sugiyono (2002: 77-78), metode purposive sampling adalah teknik penentuan sampel dengan pertimbangan tertentu, dan metode accidental sampling adalah teknik penentuan sampel berdasarkan kebetulan, yaitu siapa saja yang secara kebetulan bertemu dengan peneliti dapat digunakan sebagai sampel, bila dipandang orang kebetulan ditemui itu cocok sebagai sumber data. Aaker, et al (1998 : 406) mengatakan bahwa jumlah sampel seharusnya cukup besar sehingga bila dibagi dalam kelompok-kelompok, masing-masing kelompok akan mempunyai ukuran sampel minimal 100 atau lebih. Oleh karena itu, dalam penelitian ini ditentukan sampel setiap kelompok laki-laki dan perempuan, masing-masing sebesar 110 sampel (ditambah 10\% dari ukuran sampel minimal), sehingga jumlah total sampel sebesar 220.

\section{Teknik nalisis data}

\section{Moderator Regression Analysis (MRA)}

Kerangka kerja Moderator Regression Analysis (MRA) terdiri dari tiga persamaan regresi bertingkat dan membandingkan perubahan $\mathrm{R}^{2}$ diantara ketiganya yang menentukan secara tepat tipe efek moderator yang terjadi (Ghozali, 2008 :197-210).

Persamaan regresi tersebut sebagai berikut :

$$
Y=\alpha+\beta_{1} X_{1}+\beta_{2} X_{2}+\beta_{3} X_{3}+\beta_{4} X_{4}+\beta_{5} X_{5}+\beta_{6} X_{6}+\beta 6 X_{1} X_{2} X_{3} X_{4} X_{5}+e
$$

\section{Keterangan :}

$\mathrm{Y}=$ Variabel Dependen (Niat Untuk Menggunakan).

$\alpha \quad=$ Konstanta

$\beta=$ Koefisien Regresi

$\mathrm{X}_{1}=$ Persepsi Expressiveness $\quad\left(\mathrm{X}_{\mathrm{I}}\right)$

$\mathrm{X}_{2}=$ Persepsi Manfaat $\left(\mathrm{X}_{2}\right)$

$\mathrm{X}_{3}=$ Persepsi Kemudahan Penggunaan $\quad\left(\mathrm{X}_{3}\right)$

$\mathrm{X}_{4}=$ Persepsi Sosial $\left(\mathrm{X}_{4}\right)$

$\mathrm{X}_{5}=$ Persepsi Kualitas Sistem $\left(\mathrm{X}_{5}\right)$ 
$\mathrm{X}_{6}=$ Variabel moderator (gender)

$\mathrm{X}_{1} \mathrm{X}_{2} \mathrm{X}_{3} \mathrm{X}_{4} \mathrm{X}_{5}=$ Variabel Independen / Interaksi variabel moderator

\section{PEMBAHASAN}

Pada laki-laki, persepsi manfaat mempunyai pengaruh yang signifikan terhadap niat untuk menggunakan SMS banking dengan signifikan sebesar 0,000 dan koefisien regresi variabel persepsi manfaat adalah sebesar 0,432. Sedangkan pada perempuan, persepsi manfaat mempunyai pengaruh yang signifikan terhadap niat untuk menggunakan SMS banking dengan signifikansi sebesar 0,048 dan koefisien regresi variabel persepsi manfaat adalah sebesar 0,225.

Dari hasil $\mathrm{H}_{2}$, yaitu persepsi manfaat akan mempengaruhi niat untuk menggunakan SMS banking lebih kuat pada laki-laki dibandingkan perempuan. Maka hipotesis diterima, karena dapat dilihat dari nilai koefisien beta pada laki-laki nilai koefisien beta $(0,432)$ lebih besar dari perempuan yang nilai koefisien beta $(0,225)$. Hal ini menunjukkan bahwa laki-laki dianggap lebih rasional dalam mengambil keputusan dibandingkan perempuan. Hasil ini sesuai dengan penelitian yang dilakukan oleh Amin (2007).

Pada laki-laki, persepsi kemudahan penggunaan mempunyai pengaruh yang signifikansi terhadap niat untuk menggunakan SMS banking dengan signifikansi sebesar 0,009 dan koefisien regresi variabel persepsi kemudahan penggunaan adalah sebesar 0,188. Sedangkan pada perempuan, persepsi kemudahan penggunaan mempuyai pengaruh yang signifikan terhadap niat untuk menggunakan SMS banking dengan signifikansi sebesar 0,026 dan koefisien regresi variabel persepsi kemudahan penggunaan adalah sebesar 0,286.

Dari hasil $\mathrm{H}_{3}$, yaitu persepsi kemudahan penggunaan akan mempengaruhi niat untuk menggunakan SMS banking lebih kuat pada perempuan dibandingkan laki-laki. Maka hipotesisi diterima, karena dapat dilihat dari nilai koefisien beta, dimana pada laki-laki nilai koefisien beta $(-0,188)$ lebih kecil dari perempuan yang nilai koefisien beta $(0,286)$. Hal ini dimungkinkan bahwa perempuan di Surabaya mau berusaha keras untuk mempelajari tentang kemudahan bertransaksi dengan menggunakan SMS banking dibandingkan laki-laki. Hasil ini sesuai dengan penelitian yang dilakukan oleh Amin (2007).

Pada laki-laki, norma sosial mempunyai pengaruh yang signifikan terhadap niat untuk menggunakan SMS banking dengan signifikansi sebesar 0,001 dan koefisien regresi variabel norma sosial adalah sebesar 0,314. sedangkan pada perempuan, norma sosial mempunyai pengaruh yang signifikan terhadap niat untuk menggunakan SMS banking dengan signifikansi sebesar 0,017 dan koefisiensi regresi variabel norma sosial adalah sebesar 0,191. 
Dari hasil $\mathrm{H}_{4}$, yaitu norma sosial akan mempengaruhi niat untuk menggunakan SMS banking lebih kuat pada perempuan dibandingkan laki-laki. Maka hipotesis ditolak, karena dapat dilihat dari nilai koefisien beta, dimana pada laki-laki nilai koefisien beta $(0,314)$ lebih besar dari perempuan yang nilai koefisien beta $(0,191)$. Hal ini disebabkan bahwa dibandingkan perempuan, laki-laki di Surabaya lebih cepat mendapat pengaruh lingkungan sosial yang menuntutnya untuk melakukan perilaku tertentu. Hasil ini tidak sesuai dengan penelitian yang dilakukan oleh Amin (2007).

Pada laki-laki, persepsi kualitas sistem mempunyai pengaruh yang signifikan terhadap niat untuk menggunakan SMS banking dengan signifikansi sebesar 0,000 dan koefisien regresi variabel persepsi kualitas sistem adalah sebesar 0,398. Sedangkan pada perempuan, persepsi kualitas sistem mempunyai pengaruh yang signifikan terhadap niat untuk menggunakan SMS banking dengan signifikansi sebesar 0,000 dan koefisien regresi variabel persepsi kualitas sistem adalah sebesar 0,429 .

Dari hasil $\mathrm{H}_{5}$, yaitu persepsi kualitas sistem akan mempengaruhi niat untuk menggunakan SMS banking lebih kuat pada laki-laki dibandingkan perempuan. Maka hipotesis ditolak, karena dapat dilihat dari nilai koefisien beta, dimana pada laki-laki nilai koefisien beta $(0,398)$ lebih kecil dari perempuan yang nilai koefisien beta $(0,429)$. Hal ini disebabkan bahwa perempuan di Surabaya dianggap lebih mempertimbangkan resiko, keamanan dan kualitas sistem layanan SMS banking dibandingkan laki-laki. Hasil ini tidak sesuai dengan penelitian yang dilakukan oleh Amin (2007).

\section{SIMPULAN DAN SARAN}

\section{Simpulan}

Berdasarkan analisis dan pengujian hipotesis yang telah dilakukan maka diperoleh simpulan sebagai berikut :

1. Dari hasil $\mathrm{H}_{1}$, yaitu persepsi expressiveness akan mempengaruhi niat untuk menggunakan SMS banking lebih kuat pada perempuan dibandingkan laki-laki. Maka hipotesis ditolak, karena dapat dilihat bahwa nilai koefisien beta pada laki-laki $(0,192)$ lebih besar dari perempuan yang nilai koefisien beta $(0,155)$. Hal ini menunjukkan bahwa laki-laki di Surabaya lebih expressive dibandingkan perempuan. Berdasarkan hasil ini maka hipotesis penelitian tidak teruji kebenarannya.

2. Dari hasil $\mathrm{H}_{2}$, yaitu persepsi manfaat akan mempengaruhi niat untuk menggunakan SMS banking lebih kuat pada laki-laki dibandingkan perempuan. Maka hipotesis diterima, karena dapat dilihat dari nilai koefisien beta pada laki-laki nilai koefisien beta $(0,342)$ lebih besar 
dari perempuan yang nilai koefisien beta $(0,225)$. Hal ini menunjukkan bahwa laki-laki di Surabaya dianggap lebih rasional dalam mengambil keputusan dibandingkan perempuan. Berdasarkan hasil ini maka hipotesis penelitian teruji kebenarannya.

3. Dari hasil $\mathrm{H}_{3}$, yaitu persepsi kemudahan penggunaan akan mempengaruhi niat untuk menggunakan SMS banking lebih kuat pada perempuan dibandingkan laki-laki. Maka hipotesis diterima, karena dapat dilihat dari nilai koefisien beta, dimana pada laki-laki nilai koefisien beta $(-0,188)$ lebih kecil dari perempuan yang nilai koefisien beta $(0,286)$. Hal ini menunjukkan bahwa perempuan di Surabaya dianggap lebih mau berusaha untuk mempelajari tentang keputusan bertransaksi dengan menggunakan SMS banking dibandingkan laki-laki. Berdasarkan hasil ini maka hipotesis penelitian teruji kebenarannya.

4. Dari hasil $\mathrm{H}_{4}$, yaitu norma sosial akan mempengaruhi niat untuk menggunakan SMS banking lebih kuat pada perempuan dibandingkan laki-laki. Maka hipotesis ditolak, karena dapat dilihat dari nilai koefisien beta, dimana pada laki-laki nilai koefisien beta $(0,314)$ lebih besar dari perempuan yang nilai koefisien beta $(0,191)$. Hal ini disebabkan bahwa dibandingkan perempuan, laki-laki di Surabaya lebih cepat mendapat pengaruh lingkungan sosial yang menuntutnya untuk melakukan perilaku tertentu. Berdasarkan hasil ini maka hipotesis penelitian tidak teruji kebenarannya.

5. Dari hasil $\mathrm{H}_{5}$, yaitu persepsi kualitas sistem akan mempengaruhi niat untuk menggunakan SMS banking lebih kuat pada laki-laki dibandingkan perempuan. Maka hipotesis ditolak, karena dapat dilihat dari nilai koefisien beta, dimana pada laki-laki nilai koefisien beta $(0,398)$ lebih kecil dari perempuan yang nilai koefisien beta $(0,429)$. Hal ini disebabkan bahwa perempuan di Surabaya dianggap lebih mempertimbangkan resiko, keamanan dan kualitas sistem layanan SMS banking dibandingkan laki-laki. Berdasarkan hasil ini maka hipotesis penelitian tidak teruji kebenarannya.

\section{DAFTAR PUSTAKA}

Aaker, David A., Kumar V \& George S Day. 1998. Marketing Research. Sixth Edition. Canada : Jhon Wiley \& Sons.

Ancok, Djamaludin. 1995. Teknik Penyusunan Skala Pengukur. Yogyakarta : Pusat Penelitian Kependudukan UGM.

Amin, Hanudin., Suddin Lada, M.R.A Hamid \& G. H Tanakinjal. 2006. Undergraduates' Perception of SMS Banking in Labuan : An Empirical Analysis. International Journal of Bussiness and Society, Vol. 7, No. 2, pp. 21-39.

Amin, Hanudin.2007. Extending The Technology Acceptance Model for SMS Banking : Analyzing The Gender Gap Among Students. International Journal of Bussiness and Society, Vol. 8, No. 1, pp. 15-27

Azjen, Icek,.1991, The Tjeory of Planned Behavior, Organizational Behavior and Human Decision Precesses, Volume 50, pp 179-211. 
Bobeck, Donna D \& Richard C. Hatfield. 2003. An Investigation of The Theory of Planned Behavior and The Role of Moral Obligation in The Tax Compliance. Behavioral Research In Accounting, Vol. 15, pp. 13.

Davis,F.D. 1986. Technology Acceptance Model for Empirically Testing New End User Information Systems Theory and Result. Unpublished Doctoral Disertation MIT dalam Ramdhani, Neila. 2007. Model Perilaku Penggunaan IT : Pengembangan Dari Technology Acceptance Model.

Davis, F.D. 1989. Perceived Usefulness, Perceived Ease of Use, and User Acceptance of Information Technology. MIS Quarterly, Vol. 13, No. 3, pp. 319-340.

Engel, Blackwell \& Miniard. 1995. Consumer Behavior. Eight Edition. The Bryden Press.

Gefen, David Elena Karahanna \& Detmar W. Straub. 2003. Trust and TAM in Online Shopping: An Integrated Model. MIS Quarterly, Vol. 27, No. 1, pp. 51-90.

Ghozali, Imam, 2010, Structural Equation Modeling PLS, Edisi 2, Semarang: Badan Penerbit Universitas Diponegoro.

Handayani, T dan Sugiarto. 2001. Konsep dan Teknik Penelitian Gender. Malang: Pusat Studi Wanita dan Kemasyarakatan.

http://en.wikipedia.org/wiki/SMS banking

Jahangir, Nadim \& Noorjahan Begum. 2008. The Role of Perceived Usefulness, Perceived Ease of Use, Security and Privacy, and Customer Attitude to Engender Customer Adaption In The Context of Electronic Banking. Journal of Business Management, Vol. 2, No. 1, pp. 32-40.

Kotler, Philip \& Kevin Lane Keller. 2006. Marketing Management. New Jersey: Pearson Prentice Hall.

Nysveen, H., P.E Pedersen \& H. Thorbjornsen. 2005. Explaining Intention to Use Mobile Chat Services: Moderating Effects of Gender. The Journal of Consumer Marketing, Vol. 22, No. 5,pp. 247-256.

Olson, J. C \& Paul. 2001. Consumer Behavior and Marketing Strategy. Singapore : McGraw Hill.

Ramdani, 2007, Penggunaan Teknologi Dalam Bisnis Perbankan, Penerbit CV. Gemilang, Surabaya.

Seth, J.N., B Mital \& B.I Newman. 1999. Consumer Behavior. New Jersey: Prentice Hall.

Shen, Jia \& Lauren B. Erder. 2009. Exploring Intentions to Use Virtual Worlds for Business. Journal of Electronic Commerce Research. Vol. 10, No. 2, pp. 94-103.

Simamora, Bilson. 2004. Panduan Riset Perilaku Konsumen. Jakarta: PT. Gramedia Pustaka Utama.

Simamora, Bilson. 2002. Riset Pemasaran: Falsafah, Teori dan Aplikasi. Jakarta: PT. Gramedia Pustaka Utama.

Sugiyono. 2002. Metode Penelitian Bisnis. Bandung : Alfabeta.

Venkatesh, V \& F. D Davis. 1996. A Model of the Antecedents of Perceived Ease of Use: Development and Test. Decision Science, Vol. 27, No. 3, pp 451-479.

Venkatesh, V \& F. D Davis. 2000. A Theoretical Extension of the Technology Acceptance Model : Four Longitudional Field Studies. Management Science, Vol. 46, pp 186-204.

Venkatesh, V \& Morris, M.G. 2000. Why Don't Men Ever Stop to Ask for Directions? Gender, Social Influence, and Their Role in Technology and Usage Behavior. MIS Quartertly, Vol. 24, No. 1, pp 115-139.

www.bi.go.id

Zeitthaml, V.A. and M.J. Bitner, 2002. Service Marketing, New York : McGraw Hill. www.marketingpower.com 